\title{
Sediment movement and filtration in a riparian meadow following cattle use
}

\author{
R.R. McELDOWNEY, M. FLENNIKEN, G.W. FRASIER, M.J. TRLICA, AND W.C. LEININGER
}

Authors are Riparian/Wetland Ecologist, SAIC, 8100 Shaffer Parkway, Suite 100, Littleton, Colo. 80127, Natural Resource Specialist, Larimer County Open Lands, Loveland, Colo. 80537, Research Hydraulic Engineer (Retired), USDA, Agriculture Research Service, Crops Research Lab, Fort Collins, Colo. 80523, and Professors, Rangeland Ecosystem Science Department, Colorado State University, Fort Collins, Colo. 80523.

\begin{abstract}
Improper livestock grazing practices in western U.S. riparian areas may reduce the nutrient and pollutant removal function of riparian communities, resulting in degradation of surface water quality. Short duration-high intensity cattle use in $3 \times 10 \mathrm{~m}$ plots was evaluated in a montane riparian meadow in northern Colorado to quantify livestock effects on sediment movement and filtration under simulated rainfall $\left(\approx 100 \mathrm{~mm}_{\text {hour }}{ }^{-1}\right)$ plus overland flow $\left(\approx 25 \mathrm{~mm}\right.$ hour $\left.^{-1}\right)$ conditions. Four treatments: 1) control, 2) mowed to $10 \mathrm{~cm}$ stubble height, 3) trampled by cattle, and 4) cattle grazed plus trampled (grazed) were evaluated. Sixty kg of sediment was introduced to overland flow in each plot. Sediment movement was evaluated using sediment traps positioned in microchannels and on vegetation islands at 5 distances downslope from the upper end of the plots and by sediment front advancement. Most sediment deposition occurred within the first meter downslope from application. About $90 \%$ of the applied sediment was filtered from runoff within $10 \mathrm{~m}$ in the control and mowed treatments, while approximately 84 and $77 \%$ of the applied sediment was trapped in the trampled and grazed treatment plots, respectively. The primary variables that influenced sediment filtration were stem density and surface random roughness. Stem density was the most influential variable that affected sediment filtration. Cattle grazing reduced the stem density by $40 \%$. Monitoring of stem density should aid land managers in regulating cattle use of riparian communities and facilitate the protection of surface water quality from sediment in overland flow.
\end{abstract}

Key Words: Vegetation filter strip, stem density, rainfall simulation, NPS pollution, grazing, trampling

Sediment movement from upland areas is typically associated with intense precipitation events (Edwards and Owens 1991, Larson et al. 1997). Excessive sediment loads in runoff water can cause radical changes in streambed morphology, loss of aquatic habitat, reduction in storage capacity of reservoirs, and loss of aesthetic value (Novotny and Olem 1994).

Vegetated filter strips (VFS) are used as a Best Management

Research was funded by the USDA-CSREES Rangeland Research Grants Program, USDA-Agricultural Research Service, and the Colorado State University Agricultural Experiment Station. Authors wish to thank Dennis Mueller, Maxine Cottrell, and Elizabeth Nibarger for their assistance with the data collection.

Manuscript accepted 20 Oct. 01.

\section{Resumen}

Las prácticas inadecuadas de apacentamiento de ganado en áreas ribereñas del oeste de E.U.A pueden reducir la función removedora de nutrientes y contaminantes de las comunidades ribereñas, resultando en la degradación de la calidad del agua superficial. En parcelas de $3 \times 10 \mathrm{~m}$ en una pradera ribereña montana del norte de Colorado se evaluó el sistema de apacentamiento de corta duración - alta intensidad para cuantificar los efectos del ganado en el movimiento de sedimento y filtración bajo lluvia simulada $\left(\approx 100 \mathrm{~mm}\right.$ hora $\left.{ }^{1}\right)$ más condiciones de flujo superficial $\left(\approx 25 \mathrm{~mm}\right.$ hora $\left.{ }^{1}\right)$. Se evaluaron cuatro tratamientos: 1$)$ control, 2) segado a $10 \mathrm{~cm}$ de altura del rastrojo, 3) pisoteado por ganado y 4) apacentado por ganado mas pisoteado (apacentado). En el flujo superficial de cada parcela se introdujeron $60 \mathrm{~kg}$ de sedimento. El movimiento de sedimento se evaluó usando trampas de sedimento posicionadas en microcanales e islas de vegetación en 5 distancias pendiente abajo a partir de la parte superior de la parcela y por el avance del frente de sedimento. La mayoría de la deposición de sedimento ocurrió dentro del primer metro pendiente abajo del punto de aplicación. En los tratamientos control y segado aproximadamente $90 \%$ del sedimento aplicado se filtró del escurrimiento dentro de $10 \mathrm{~m}$, mientras aproximadamente de 84 a $77 \%$ del sedimento aplicado fue atrapado en las parcelas de los tratamientos pisoteado y apacentado respectivamente. Las principales variables que influenciaron la filtración de sedimento fueron la densidad de tallos y la rugosidad aleatoria de la superficie. La densidad de tallos fue la variable de mayor influencia en la filtración de sedimento. El apacentamiento de ganado redujo la densidad de tallos en $\mathbf{4 0 \%}$. El monitoreo de la densidad de tallos debe ayudar a los manejadores de tierras en regular el uso de las comunidades ribereñas por el ganado y facilitar la protección de la calidad de agua superficial del sedimento en el flujo superficial.

Practice to remove sediment and other types of non-point source (NPS) pollution from overland runoff (Dillaha 1989, Magette et al. 1989). The efficiency of VFS in trapping sediment depends on the microtopography, vegetation cover and density, slope, length of the buffer strip, and the type and degree of surface disturbance (NRC 1993, Landry and Thurow 1997). Because of their location adjacent to surface waters, riparian areas often function as VFS to trap sediment derived from upland sources before it reaches the stream (Cooper et al. 1987, Osborne and Kovacic 1993, Hairsine 1996, Pearce et al. 1998b). Though livestock use has been one of 
the most important modifiers (i.e. soil compaction, defoliation, and physical damage to vegetation) of western United States riparian areas (Elmore and Beschta 1987), the effects of cattle use on sediment trapping ability of riparian filter strips have not been examined. The objectives of this study were to determine the effects of cattle trampling and grazing on vegetation and soil surface variables, and to evaluate their effects on sediment movement and filtration in a montane riparian meadow under simulated rainfall and overland flow conditions.

\section{Methods and Materials}

\section{Study Site}

Research was conducted in the summer (June-August) of 1997, in the Roosevelt National Forest approximately $80 \mathrm{~km}$ northwest of Fort Collins, Colo. at an elevation of $2,500 \mathrm{~m}$, in a riparian meadow adjacent to Sheep Creek ( $40^{\circ} 56^{\prime} 58^{\prime \prime} \mathrm{N}$ Lat., $105^{\circ} 40^{\prime} 51^{\prime \prime}$ W Long.). Dominant vegetation in the meadow included shrubby cinquefoil (Potentilla fruticosa L.), Kentucky bluegrass (Poa pratensis L.), tufted hairgrass (Deschampsia caespitosa (L.) Beauv.), small-winged sedge (Carex microptera Mack.), water sedge ( $C$. aquatilus Wahl), Baltic rush (Juncus balticus Willd.), and various forb species such as marsh marigold (Caltha leptosepala D.C.) and yarrow (Achillea lanulosa L.).

Soils within the Sheep Creek riparian area are primarily Fluvaquents. These sandy to clay loam soils have a water table that is commonly at a depth of less than 30 $\mathrm{cm}$ at some time during the spring and summer. A highly organic $(>7 \%)$ ' A' horizon, up to $20 \mathrm{~cm}$ thick, covered the study area (USDA 1980, Frasier et al. 1998).

Sixteen, 3 x 10 m plots, established during previous experiments at Sheep Creek (Fernald 1997, Pearce et al. 1998a), were used in this study. All plots had been mowed to a $10 \mathrm{~cm}$ stubble height the previous 2 summers. Paired plots ( $3 \mathrm{~m}$ apart) were delineated with $15 \mathrm{~cm}$ high steel edging placed $6 \mathrm{~cm}$ into the soil and oriented perpendicularly to Sheep Creek. A 'Swanson type' large rotating boom rainfall simulator was used to simulate an intense rainstorm over the plots (Swanson 1965, Laflen et al. 1991, Simanton et al. 1991).

\section{Treatments}

One of the following treatments was applied to each plot:
Control: Undisturbed plots with natural vegetation approximately $20 \mathrm{~cm}$ tall.

Mowed: Plots were mowed to a uniform $10 \mathrm{~cm}$ stubble height, with the clippings removed.

Trampled: Three muzzled $320 \mathrm{~kg}$ heifers (stocking rate $\approx 200$ Animal Unit Days (AUD)/ha) were placed on these plots for 8 hours (1630 to 2030 hours and 0430 to 0830 hours).

Grazed plus trampled: Three $320 \mathrm{~kg}$ heifers (stocking rate $\approx 200$ AUD/ha) were taken off feed for 12 hours and then placed on these plots for a total of 8 hours, which coincided with their normal feeding times of 1630 to 2030 hours and 0430 to 0830 hours.

The mowed treatment represented canopy reduction without hoof action. The trampled treatment was used to examine the hoof action of cattle without grazing removal of vegetation, while the grazed treatment represented the combined effects of canopy removal and hoof action.

\section{Plot Characterization}

Cover, soil microtopography (i.e., random roughness), vegetation stem density, and aboveground biomass were assessed to determine their effects on sediment movement and deposition. Whenever possible, a catwalk was used above the plots to minimize surface disturbance.

\section{Cover}

Cover by class (i.e., litter, bare ground, forbs, grasses, and shrubs) at the soil surface was determined with a 10 point pin frame before treatment (adapted from Hofmann et al. 1983, Devaurs and Gifford 1984). Ten random pin frames (i.e., 100 points) within each plot were taken. The plots were sampled again after the posttreatment rainfall simulation.

\section{Random Roughness}

Surface microtopography was measured with a 100 point $(10 \times 9.6 \mathrm{~cm}$ grid $)$ elevation pin table $(0.6 \times 2 \mathrm{~m})$, positioned lengthwise across the center of each plot (Linse et al. 2001). Pin height ( $\mathrm{mm}$ ) above the table was measured with a digital caliper. The standard deviation of all 100 pin elevations was used as an index of surface random roughness (Hairsine et al. 1992, Frasier et al. 1998).

\section{Vegetation}

Vegetation density (stems $\mathrm{m}^{-2}$ ) was determined by class (i.e., grasses, forbs, sedges, and Baltic rush) at ground level using a $100 \mathrm{~cm}^{2}$ quadrat. Stems within each quadrat were counted at 10 random locations within the lower $2 / 3$ of each plot before all treatments and following the cattle grazing and trampling treatments. Stem density was assumed to remain constant on the control and mowed plots; therefore, stem density was only sampled prior to treatments on these plots.

Vegetation was clipped to ground level in $1 / 8 \mathrm{~m}^{2}$ circular quadrats and bagged to estimate aboveground biomass. Five biomass samples were clipped at random locations in each plot before and after grazing, after mowing, and in the control plot. The trampled treatment was only sampled prior to treatment. Samples were dried in a forced air oven at $50^{\circ} \mathrm{C}$ for 72 hours prior to weighing.

\section{Rainfall Simulations}

Two simulation runs, approximately 24 hours apart, were made on each plot pair; one before (pre-conditioning) and one after the treatments were applied. Rainfall was simulated at an approximate rate of $100 \mathrm{~mm} \mathrm{hour}^{-1}$. This amount of simulation water applied was almost double that used in previous studies at Sheep Creek by Fernald (1997) and Pearce et al. (1998a), and was chosen, not to duplicate natural storm events, but to provide adequate flow to move sediment. Actual rainfall application rate of the simulator was measured with a $20 \mathrm{~cm}$ diameter rain gage equipped with a bubble gage recorder positioned between the paired plots. Distribution of total simulated rainfall was measured with 6 small plastic rain gages randomly located within each plot border (Frasier et al. 1998).

Overland flow during pre- and posttreatment runs was simulated by spraying water at a rate equivelent to $25 \mathrm{~mm}^{-1}$ over the entire plot onto a $3.0 \times 0.6 \mathrm{~m}$ tilted ( $6 \%$ slope) tray at the upper edge of each plot. Actual application rate was determined for each simulation run by volumetric sampling of the spray bar nozzles. Runoff was measured at the bottom of each plot with a calibrated flume attached to a pressure transducer bubble gage recorder. Discharge was recorded at $1 \mathrm{~min}$ intervals.

\section{Pre-treatment Rainfall Simulation}

Plots were preconditioned for 1 hour with simulated rainfall and overland flow, 24 hours prior to treatment. Once steady- 
state (equilibrium) runoff was achieved, a dye tracer was applied as a line source across the plots at 2 locations ( 3 and $6 \mathrm{~m}$ downslope from the top of the plots) to delineate microchannel flow paths and rate of water front advancement down the plots. Flow channels were delineated with spray paint for placement of sediment traps before the post-treatment simulation event.

\section{Post-treatment Rainfall Simulation}

Following treatment, rainfall plus overland flow was again simulated over paired plots. When equilibrium runoff was achieved, sediment of known particle size was introduced to overland flow on each plot at a rate of $3 \mathrm{~kg}$ every $2 \mathrm{~min}$. A total of $60 \mathrm{~kg}\left(\approx 20,000 \mathrm{~kg} \mathrm{ha}^{-1}\right)$ of sediment was applied. This rate was selected based on previous overland flow studies at Sheep Creek where $30 \mathrm{~kg}\left(\approx 10,000 \mathrm{~kg} \mathrm{ha}^{-1}\right)$ of sediment was applied (Pearce et al. 1998a, 1998b). Reported levels of sediment that might reach a riparian area in overland flow are usually considerably less $(\approx 5,000$ $\left.\mathrm{kg} \mathrm{ha}^{-1}\right)$ than the amount used in this study (Buckhouse and Mattison 1980, Buckhouse and Gaither 1982). The introduced sediment was white and mixed by weight from 2 commercial ground silica products, $60 \%$ SIL-CO-SIL ${ }^{\circledR} 250$ and $40 \%$ MIN-USIL ${ }^{\circledR} 5$, with a particle size distribution of $31.6 \%$ very fine sand (> $50 u \mathrm{~m}$ ), $41.8 \%$ silt $(2-50 u \mathrm{~m})$ and $26.6 \%$ clay $(<2 u \mathrm{~m})$. This sediment had a higher portion of fines $(<50 u \mathrm{~m})$ than the soils on the uplands in the Sheep Creek area and thus, would be more easily moved by the water (Pearce et al. 1998a).

A total of 15 runoff samples were collected at the base of each plot for sediment yield determination. Beginning with the onset of equilibrium runoff, eleven, 950 $\mathrm{ml}$ grab samples of runoff were taken at 4 min intervals. When the simulator was shut off, discharge decreased, and the remaining 4 runoff samples were $500 \mathrm{ml}$ each. Each runoff sample was filtered through pre-weighed high wet strength 15 $\mathrm{cm}$ diameter filter paper with pore diameters of $1 \mu \mathrm{m}$. The samples were dried in a forced draft oven at $50^{\circ} \mathrm{C}$ for 4.5 hours and re-weighed. Sediment concentration was determined for each sample and these data were correlated with discharge measurements to arrive at an estimated total sediment yield for each plot within each treatment. Only negligible amounts of organic residues were collected in runoff samples (McEldowney 1999).

Table 1. Responses of selected variables for 4 treatments applied to a montane riparian meadow. Similar letters following means in a row indicate non-significant differences $(P>0.10)$.

\begin{tabular}{lllll}
\hline \hline & \multicolumn{4}{c}{ Treatment } \\
\cline { 2 - 5 } Variable & Control & Mowed & Trampled & Grazed \\
\hline Plot slope (\%) & $3.8 \mathrm{a}$ & $3.6 \mathrm{a}$ & $4.2 \mathrm{a}$ & $3.8 \mathrm{a}$ \\
Litter cover $(\%)$ & $63 \mathrm{a}$ & $65 \mathrm{a}$ & $61 \mathrm{a}$ & $62 \mathrm{a}$ \\
Stem density (\# stems $\left.\mathrm{m}^{-2}\right)$ & $5,300 \mathrm{ab}$ & $5,500 \mathrm{a}$ & $4,700 \mathrm{~b}$ & $3,300 \mathrm{c}$ \\
Random roughness $(\mathrm{mm})$ & $13.0 \mathrm{a}$ & $11.9 \mathrm{a}$ & $12.4 \mathrm{a}$ & $13.6 \mathrm{a}$ \\
Aboveground biomass $\left(\mathrm{kg} \mathrm{ha}^{-1}\right)$ & $2,300 \mathrm{a}$ & $1,700 \mathrm{a}$ & - & $900 \mathrm{~b}$ \\
Coarse particle movement $(\mathrm{mm})$ & $726 \mathrm{~b}$ & $733 \mathrm{~b}$ & $971 \mathrm{~b}$ & $1,279 \mathrm{a}$ \\
Sediment filtration* $\left(\mathrm{kg} \mathrm{ha}^{-1}\right)$ & $19,600 \mathrm{a}$ & $19,800 \mathrm{a}$ & $18,700 \mathrm{a}$ & $17,300 \mathrm{~b}$ \\
\hline
\end{tabular}

$* 20,000 \mathrm{~kg} \mathrm{ha}^{-1}$ of sediment applied to all plots.

\section{Sediment Movement}

Sediment transport and deposition was determined using 5 rows of 4 sediment traps at $1,1.5,2.0,2.5$, and 3.0 m downslope from the top of each plot. Two traps in each row were placed within microchannels and 2 in vegetation 'islands' between microchannels. Sediment traps were plastic cups, $6.2 \mathrm{~cm}$ diameter at the top and $7.5 \mathrm{~cm}$ tall. The traps were placed with their tops flush with the soil surface. Sediment caught in the 2 channel traps or the 2 island traps within a row was composited by location and was later vacuum filtered, dried and weighed. The maximum distance that coarse particles traveled was visually estimated and measured from the top of each plot after the rainfall simulation.

\section{Experimental Design}

The 4 treatments were organized in a randomized complete block design with 4 blocks that were on an aridity gradient perpendicular to the stream. A repeated measures analysis of variance was used to determine differences among treatments and between sediment trap position (in or out of microchannels) and distance downslope. Sediment trap data were transformed to $\log _{10}$ scale before analysis, but results are reported as actual values. Analysis of covariance was used to determine relationships among treatments, vegetation characteristics, soil microtopography, and flow parameters with coarse particle sediment movement. Sediment yield was analyzed to determine treatment effects $(P \leq 0.10)$. Multiple regression models were constructed for sediment trap data and sediment yield by treatment using a forward selection process, and for coarse particle movement using a backward selection process. Significance was accepted at $\mathrm{P} \leq$ 0.10 . Data are presented as main effects unless there was a significant interaction. Data analyses were done using $\mathrm{SAS}^{\circledR}$ for Windows ${ }^{\circledR}\left(\right.$ SAS $\left.^{\circledR} 1996\right)$.

\section{Results and Discussion}

\section{Cover}

Cover (live + litter) was greater than $96 \%$ on all plots. Litter was the dominant ground cover (61 to $65 \%$ ) for all treatments, with no differences among treatments (Table 1). Ground cover classes such as sedges, moss, and forbs also were not affected by treatments. The large amount of litter likely reduced soil compaction and alterations to the soil surface that may have been caused by hoof action of the heifers.

\section{Random Roughness}

Random roughness of the soil surface was similar among treatments (Table 1). In North Dakota, Hofmann and Ries (1991) determined there were no differences in surface roughness among their grazed and ungrazed treatments. Their index of surface roughness was the variance from 10 pin elevations spaced $50 \mathrm{~mm}$ apart. Frasier et al. (1998) found no differences in surface random roughness among stubble height treatments for riparian communities, and concluded that surface random roughness was very difficult to adequately characterize. As several authors have suggested (Linse 1992, Fernald 1997, Frasier et al. 1998, Pearce et al. 1998b), the connectivity of microtopographical features may be more important for water routing than is random roughness itself.

\section{Vegetation}

Cattle grazing decreased stem density by $40 \%$ compared to the control (Table 1 ). Specifically, forb stem densities were decreased by $50 \%$ on both trampled and grazed plus trampled treatments, as compared to the control. Grass stem densities were reduced approximately $40 \%$ on the grazed plots compared to the control. The grazed (plus trampled) treatment had the lowest average stem density, because cattle removed stems by both pulling up 


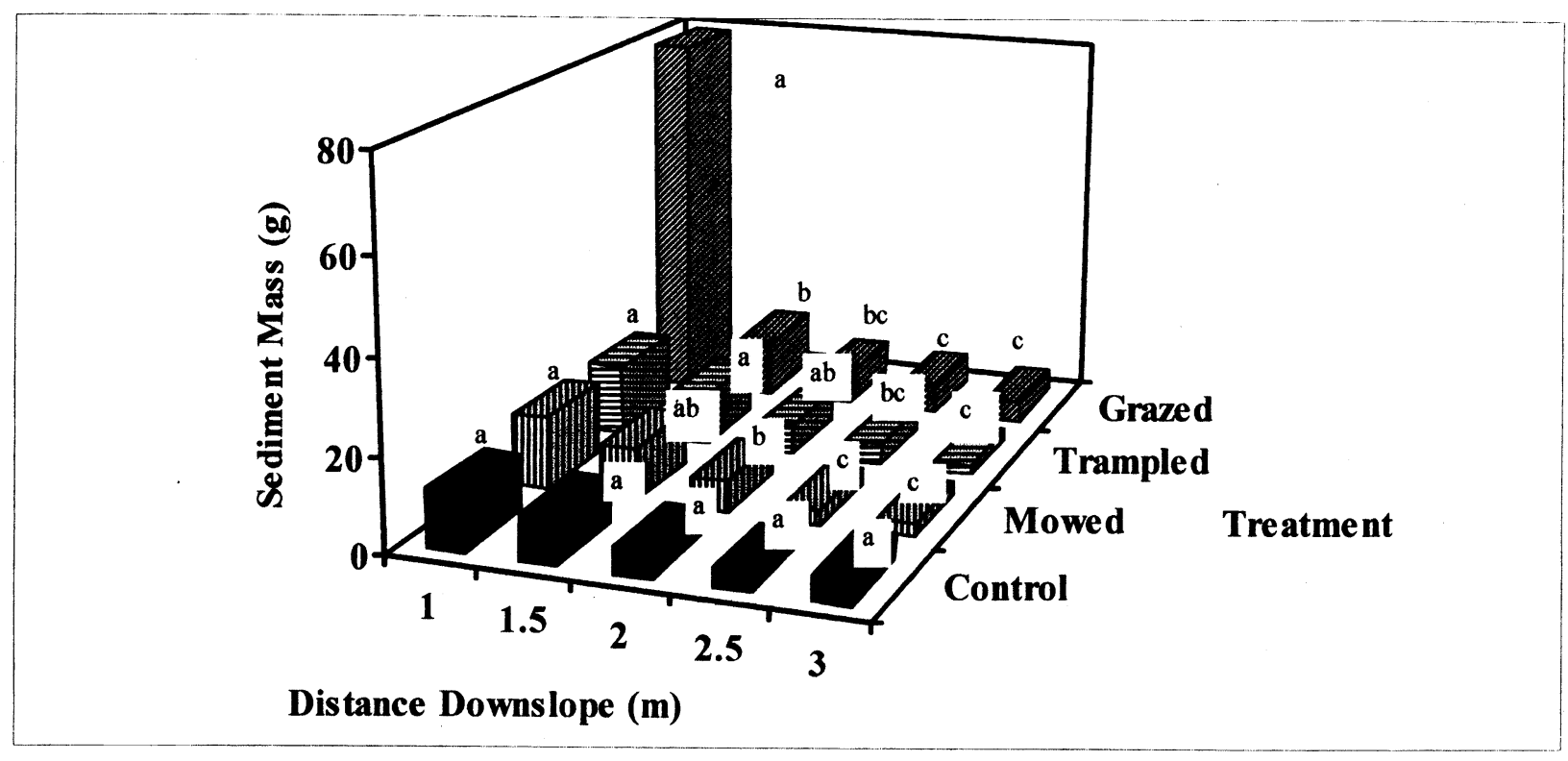

Fig. 1. Sediment deposition in traps positioned within microchannels. Comparison of distances done separately within each treatment. Values within the same position with the same letter are not significantly different $(P>0.10)$.

stems with grazing and through hoof shear (Kauffman et al. 1983, Abdel-Magid et al. 1987). These differences imply that, under these very wet soil conditions, the relative impact of hoofs is less on changing plant stem density than the actual animal grazing. The reduction in stem density following the cattle treatments subsequently impacted microchannel, runoff, and sediment movement characteristics (Flenniken et al. 2001).

Aboveground biomass was approximately $60 \%$ less on grazed plots than on control plots. However, there were no significant differences between mowed and grazed plots for aboveground biomass (Table 1). Forage utilization of grazed plots ranged from 12 to greater than $75 \%$, with a mean utilization level of $54 \%$.

\section{Sediment Traps}

Analysis of sediment trap data indicated a significant 3-way interaction among treatments, position (in channels vs. on islands), and distance downslope. On grazed plots, there was almost 4 times the amount of sediment in channel traps placed $1 \mathrm{~m}$ downslope than at the next distance $(1.5 \mathrm{~m})$ downslope (Fig. 1). The large difference between the amount of sediment caught within this half meter distance may have resulted from insufficient energy in microchannel flow to transport sediment beyond $1 \mathrm{~m}$ downslope.

The greater quantity of sediment trapped in channels in the first meter of the grazed plots resulted from differences in both vegetation and flow characteristics. Cattle grazing reduced vegetation barriers to sediment movement that were present on the trampled, mowed, and control treatments. With less sediment trapped within the vegetation, there was more sediment available to be transported and deposited in the microchannels. Additionally, with less vegetative cover, sediment was subjected to raindrop splash and transport phenomena into the channel traps (Thurow et al. 1986). Microchannel sinuosity was also decreased on the grazed plots (Flenniken et al. 2001), which may have increased the transport capacity of sediments in channels to the traps within the first meter of the grazed plots.

On the mowed and trampled plots most of the sediment in the microchannels was trapped in the top 1-2 m. On the trampled plots more sediment was trapped within the first $1 \mathrm{~m}$ to $1.5 \mathrm{~m}$ distances downslope than at $2.5 \mathrm{~m}$ and $3 \mathrm{~m}$ positions (Fig. 1). On mowed plots there was more sediment in the microchannel traps in the first meter than at $2,2.5$, or $3 \mathrm{~m}$ downslope. In contrast, there were no significant differences in the amounts of sediment caught in traps positioned in microchannels at any distance downslope for the control plots.

The general trend that more sediment was caught in traps positioned in microchannels than in islands for each treatment was expected since microchannels were topographically lower and carried the majority of flow (Fig. 1 and 2). The greater mass of sediments that moved in microchannels was a result of increased overland flow transport capacity that resulted from increased flow velocity and depth in microchannels than in interspace areas (Rogers and Schumm 1991, Flenniken 1999). More sediment was caught in island traps at the $1 \mathrm{~m}$ distance than at 2.5 or $3 \mathrm{~m}$ distances (Fig. 2). The presence of sediment in island traps may have resulted from particle movement into traps from raindrop splash detachment, and from overland flow in areas where the flow was deep enough to submerge traps on vegetation islands. Vegetated filter strips have been shown to become less effective once overland flow depth exceeds vegetation height (Pearce et al. 1997). If vegetation height is greatly decreased by cattle grazing and trampling, then overland flow depths may exceed the height of the vegetation.

\section{Coarse Particle Movement}

Greater downslope coarse particle (sand) movement occurred on the grazed treatment than on the trampled, mowed, or control treatments (Table 1). However, there were no significant differences in sand movement among these 3 other treatments. Sand moved $78 \%$ farther downslope from the upper edge of grazed plots as compared with control plots. Since coarse particle movement downslope on grazed plots was greater than on trampled plots, this indicated that grazing removal of canopy cover and stems was more important than the effect of trampling alone. Variables that most influenced the 


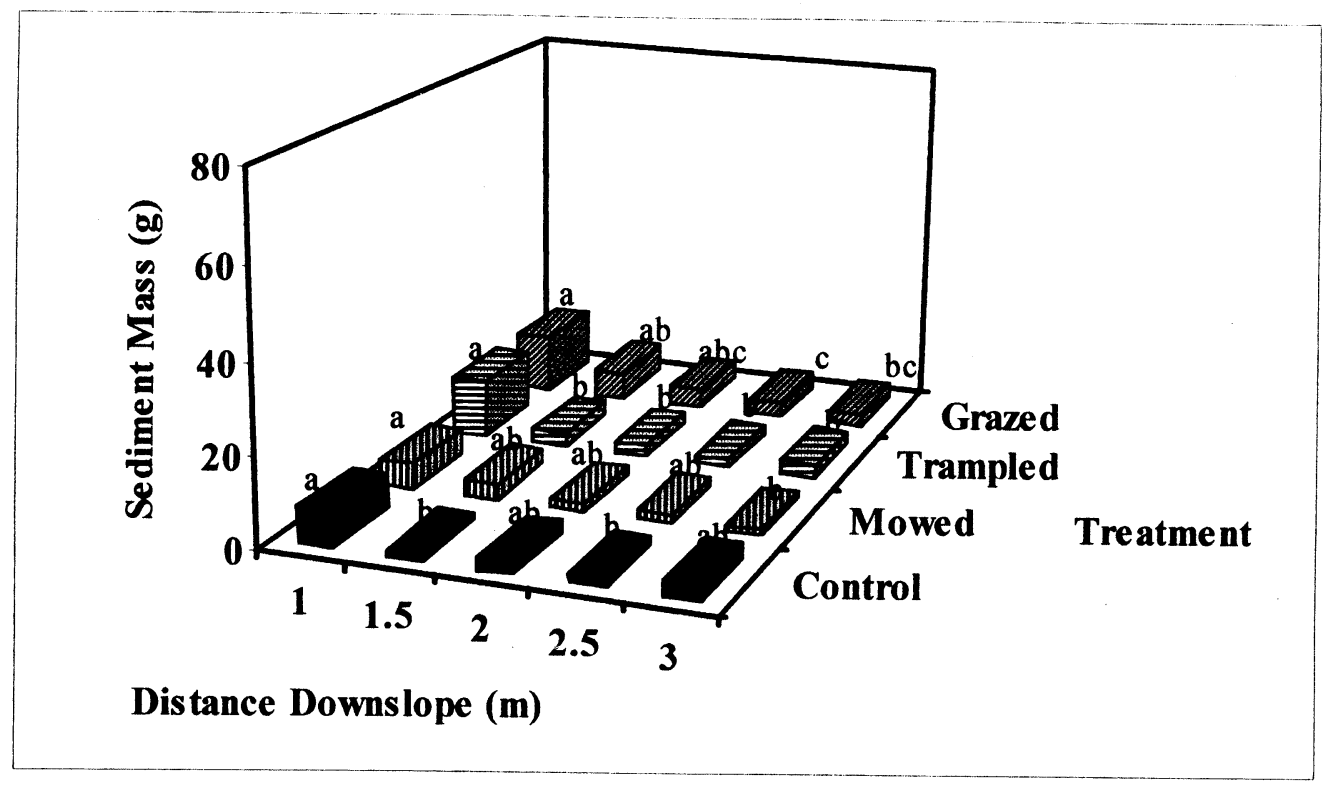

Fig. 2. Sediment deposition in traps positioned on islands between microchannels. Comparison of distances done separately within each treatment. Values within the same position with the same letter are not significantly different $(P>0.10)$.

downslope movement of coarse sediment were stem density and microchannel flow velocity (Table 2 ).

\section{Sediment Filtration}

Sediment filtration in the grazed treatment was significantly lower than in the trampled, mowed, or control treatments, which were not different from one another (Table 1). Simulated trampling studies have been conducted elsewhere to evaluate the effects of trampling on sediment yield. Packer (1953) found that increased trampling generally caused increased soil loss. However, simulated trampling had no effect on soil loss when initial ground cover was over $90 \%$. In another simulated trampling experiment, Dadkhah and Gifford (1980) showed that grass cover was the most important variable affecting sediment yield, regardless of trampling level. They recommended the maintenance of $50 \%$ ground cover for watershed protection for sites with loamy soil and $15 \%$ slopes.

Stem density was the primary variable that affected total sediment yield in the present study. Sixty four percent of the measured variability in sediment yield

Table 2. Predictive models for sediment movement and sediment yield in a montane riparian meadow.

\begin{tabular}{llr}
\hline \hline Dependent variable & Independent variables and regression equation & $\mathrm{r}^{2}$ \\
\hline Coarse particle movement & & \\
downslope $(\mathrm{mm})$ & $1267.11-0.015\left(\right.$ stems m$\left.^{-2}\right)+9175.86\left(\right.$ flow velocity $\left.\mathrm{m} \mathrm{sec}^{-1}\right)$ & 0.59 \\
Sediment yield $\left(\mathrm{kg} \mathrm{ha}^{-1}\right)$ & $9778.1-0.998\left(\right.$ stems m$\left.^{-2}\right)-171.14$ surface roughness index $(\mathrm{mm})$ & 0.78 \\
\hline
\end{tabular}

among treatments was accounted for by stem density alone. Surface random roughness values were poor estimators of sediment yield when used alone. However, when used in conjunction with stem density, random roughness improved our ability by $14 \%$ to predict sediment yield (Table 2 ). Both of these factors exert friction on overland flow.

The interaction between discharge and bed friction directly influences sediment transport; as discharge increases, the energy available to carry sediment also typically increases. Several studies have shown the importance of friction created by stem density as it affects overland flow. Fernald (1997) found that an effective friction subfactor, that was derived from stem width to stem spacing ratio, better estimated discharge than did plot averaged friction subfactors or microchannel effective friction subfactors based on ground cover class, soil texture, and standing plant biomass. A field flume study conducted by Prosser et al. (1995) showed that critical shear stress was reduced by half when grass was clipped to a $10 \mathrm{~cm}$ stubble height, but that rates of sediment transport were still very low. With complete removal of plant stems, critical shear stress was reduced to $11-38 \%$ of control plot values. This allowed more sediment to be transported on clipped plots. Prosser et al. hypothesized that 2 flow regimes existed once herbaceous vegetation was overwhelmed by water; a slower flow through vegetation stems with a more rapid laminar flow above them. This shear stress partitioning suggested that on a densely grassed surface, more than $90 \%$ of the resistance to flow was caused by plant stems (Prosser et al. 1995). In a small plot study in Arizona, Abrahams et al. (1994) determined that plant stems and litter cover were the primary variables that created resistance to overland flow on grassland plots clipped to a height of 2 to $3 \mathrm{~cm}$.

Results from this present experiment supported findings of Pearce et al. (1997, 1998a, 1998b) that stubble height was not a good indicator for sediment filtration in a montane riparian community. Pearce et al. (1998a, 1998b) determined that sediment yield neither decreased nor increased as vegetation stubble height increased, as water flow depth was less than the height of the stubble. They concluded that accurate prediction of sediment filtration from overland flow required the consideration of a combination of vegetation and soil surface variables such as stem density, forb cover, amount of bare ground, silt content of soil, clay content of introduced sediment, amount of runoff, and slope.

Variables that were considered in this present study, but had little effect on sediment yield or became insignificant when considered simultaneously with stem den- 
sity, were bare ground, litter cover, moss cover, microchannel sinuosity, drainage density, and rainfall intensity. Because both the amount and type of ground cover among treatments were similar, and probably caused analogous turbulent flows at the soil-water interface, the influence of ground cover on sediment yield was similar for all 4 treatments. There can be no doubt of the importance of ground cover to sediment transport, but when ground cover is similar among treatments the influence of other variables, such as stem density, is dominant.

Increased microchannel sinuosity can also influence sediment yield (Thurow et al. 1988, Spaeth et al. 1994, Prosser et al. 1995 ) by reducing flow velocity, thus reducing sediment transport capacity. In a companion study to ours, short durationhigh intensity cattle trampling resulted in a reduction of microchannel sinuosity (Flenniken et al. 2001). This reduction, however, did not explain as much variability in sediment yield as did stem density.

At the watershed scale, drainage density and sediment yield are typically thought to be negatively correlated with vegetaion cover and positively correlated with maximum precipitation events (Abrahams 1972, Dunne and Leopold 1978). At the scale of this present study, cattle trampling and grazing resulted in a decrease in drainage density (Flenniken 1999) and an increase in sediment yield (McEldowney 1999). A few larger microchannels with greater flows should result in increased sediment transport. A good correlation between sediment yield and drainage density, however, was not found. The decrease in drainage density on the cattle disturbed plots may indicate a homogenization effect by cattle on spatial variability of the vegetation. Additional research is needed to determine spatial variability of vegetation in riparian areas as it affects sediment filtration.

Canopy removal by cattle or by mowing may have permitted more raindrops to strike the sediment laden overland flow, and thereby facilitate the movement of sediment downslope. Rainfall intensity over the very narrow range experienced in this study had little effect on total sediment yield. However, splash resulting from raindrop impact could have transported sediment laden drops short distances (both up- or down-hill), such as into the island sediment cups. Most of the plot area was covered with a layer of water during equilibrium runoff that ranged in depth from 14 to $36 \mathrm{~mm}$ (Flenniken 1999), and likely reduced rain- drop impact sufficiently to nullify the effect of rainfall intensity on sediment reentrainment (Hairsine et al. 1992). Moss (1988) found that raindrop impact on turbulent flow was minor and had little effect on sediment transport. He found that raindrop impact was most important in reentrainment of bedload size $(0.2 \mathrm{~mm})$ particles. Because of the relatively low energy required to transport fine particles such as silt and clay (suspended load), raindrop impact would probably not affect their transport.

\section{Conclusions}

Studies where sediment movement as affected by cattle activity and differences in sediment movement in channels versus islands could not be found. However, there are studies that have shown that vegetation height was less influential than canopy cover in reducing downslope sediment movement (Pearce et al. 1998a). Down slope coarse particle movement did not differ between control and mowed treatments in this present study. These results agreed with Pearce et al. (1998a) who determined that there were no differences in sand movement between $10 \mathrm{~cm}$ stubble height and natural vegetation height (about $22 \mathrm{~cm}$ ) treatments in a grass/sedge community.

Treatment, positioning of traps in channels or islands, and distance downslope were all significant factors that affected sediment deposition in traps. Sediment traps were used in this study as indicators of sediment transport, not sediment retention. Therefore, the greater mass of sediment caught in traps on grazed plots positioned in channels at $1 \mathrm{~m}$ downslope compared with the other 4 distances reflected greater transport of sediment on these plots. Lower vegetation stem density and aboveground biomass on grazed plots reduced the ability of these plots to retain sediment and allowed transport of sediment into channel traps. Microchannels in riparian areas act as conduits to transport sediment downslope. The straightening and reduction in density of these microchannels that resulted from cattle grazing caused deeper flow depths and increased flow velocities. These straighter and deeper microchannels then had greater sediment transport capacity and sediment movement downslope (Flenniken et al. 2001).

Sediment filtration was less in both the grazed $(77 \%)$ and trampling $(84 \%)$ treat- ments as compared with control and mowed treatments where sediment filtration was about $90 \%$. These filtration values were slightly less than those found by Pearce et al. (1998b) for the same montane community. In that study, both the rainfall intensity $\left(85 \mathrm{~mm} \mathrm{hr}^{-1}\right)$ and the amount of sediment that was added to the plots $(30 \mathrm{~kg})$ were both significantly lower than in this present study.

The density of herbaceous plant stems was the most important variable that affected sediment filtration in this present study. As stem density increased, so did sediment filtration. Cattle grazing not only reduced the height of vegetation, but stem density was decreased as well. This caused stubble height alone to be a poor predictor of sediment filtration in areas grazed by cattle. Friction provided by more dense plant stems on both the mowed and control treatments attenuated overland flow velocities and increased sediment deposition (Flenniken et al. 2001). In addition, use of the standard deviation for surface random roughness quantification also improved the prediction model for sediment yield.

Under the extreme conditions of this study (i.e., intense rainfall, high sediment loading, and high stocking rate of cattle), stem densities of approximately 5,000 stems $\mathrm{m}^{-2}$ were effective in trapping $90 \%$ of the sediment applied. In areas where riparian filtration of NPS pollution is a primary management goal, monitoring of stem density could be an important tool in the decision making process. Results of this research supported the findings of other studies (Lowrance et al. 1986, Cooper et al. 1987, Welsch 1991, Daniels and Gilliam 1996, Hairsine 1996, Pearce et al. 1998b) that indicated that riparian filtration could be effective for reducing NPS pollution to surface waters. In addition, our findings indicated that properly managed cattle grazing along the outer edges of montane riparian meadows might be compatible with sediment filtration goals.

The importance of stem density in this montane riparian community for sediment filtration indicates that stem density data might be useful in modeling sediment transport. Furthermore, this research has demonstrated the necessity to consider riparian areas separately from adjacent uplands. If this is done, improved estimates of sediment delivery to a stream or lake should result. 


\section{Literature Cited}

Abdel-Magid, A.H., M.J. Trlica, and R.H. Hart. 1987. Soil and vegetation responses to simulated trampling. J. Range Manage. 40:303-306.

Abrahams, A.D. 1972. Drainage densities and sediment yields in Eastern Australia. Aust. Geo. Studies 10:19-41.

Abrahams, A.D., A.J. Parsons, and J. Wainwright. 1994. Resistance to overland flow on semiarid grassland and shrubland hillslopes, Walnut Gulch, southern Arizona. J. Hydrol. 156:431-446.

Buckhouse, J.C. and R.E. Gaither. 1982. Potential sediment production within vegetative communities in Oregon's Blue Mountains. J. Soil and Water Cons. $37: 120-122$.

Buckhouse, J.C. and J.L. Mattison. 1980. Potential soil erosion of selected habitat types in the High Desert Region of central Oregon. J. Range Manage. 33:282-285.

Cooper, J.R., J.W. Gilliam, R.B. Daniels, and W.P. Robarge. 1987. Riparian areas as filters for agricultural sediment. Soil Sci. Soc. Amer. J. 51:416-420.

Dadkhah, M. and G.F. Gifford. 1980. Influence of vegetation, rock cover, and trampling on infiltration rates and sediment production. Water Resour. Bull. 16:979-986.

Daniels, R.B. and J.W. Gilliam. 1996. Sediment and chemical load reduction by grass and riparian filters. Soil Sci. Soc. Amer. J. 60:246-251.

Devaurs, M. and G.F. Gifford. 1984. Variability of infiltration within large runoff plots on rangelands. J. Range Manage. 37:523-528.

Dillaha, T.A. 1989. Water quality impacts of vegetative filter strips. Paper No. 89-2043. Am. Soc. Agr. Eng. St. Joseph, Mich. 9 p.

Dunne, T. and L.B. Leopold. 1978. Water in Environmental Planning. W.H. Freeman and Co. New York. 818 p.

Edwards, W.M. and L.B. Owens. 1991. Large storm effects on total soil erosion. J. Soil and Water Cons. 46:75-78.

Elmore, W. and R.L. Beschta. 1987. Riparian areas: perceptions in management. Rangelands 9:260-266.

Fernald, A.G. 1997. Microtopographic flow paths and riparian surface hydrology. Ph.D. Diss. Colorado State Univ. Fort Collins, Colo. $136 \mathrm{p}$.

Flenniken, M. 1999. Flow characteristics and sediment movement in a montane riparian ecosystem. M.S. Thesis. Colorado State Univ. Fort Collins, Colo. 99 p.

Flenniken, M., R. McEldowney, G.W. Frasier, W.C. Leininger, and M.J. Trlica. 2001. Runoff response in a montane riparian area following cattle use. J. Range Manage. 54:567-574.

Frasier, G.W., M.J. Trlica, W.C. Leininger, R.A. Pearce, and A. Fernald. 1998. Runoff from simulated rainfall in 2 montane riparian communities. J. Range Manage. 51:315-322.
Hairsine, P.B. 1996. Comparing grass filter strips and near-natural riparian zones for trapping sediment and sorbed nutrients. p. 109. In: Paper presented at ASSSI and NZSSS National Soils Conference, July 1996 - Oral paper.

Hairsine, P.B., C.J. Moran, and C.W. Rose. 1992. Recent developments regarding the influence of soil surface characteristics on overland flow and erosion. Aust. J. Soil Res. 30:249-264.

Hofmann, L. and R.E. Ries. 1991. Relationship of soil and plant characteristics to erosion and runoff on pasture and range. J. Soil and Water Cons. 46:143-147.

Hofmann, L., R.E. Ries, and J.E. Gilley. 1983. Relationship of runoff and soil loss to ground cover of native and reclaimed grazing land. Agron. J. 75:599-602.

Kauffman, J.B., W.C. Krueger, and M. Vavra. 1983. Effects of late season cattle grazing on riparian plant communities. J. Range Manage. 36:685-690.

Laflen, J.M., L.J. Elliot, J.R. Simanton, C.S. Holzhey, and K.D. Kohl. 1991. WEPP Soil erodibility experiments for rangeland and cropland soils. J. Soil and Water Cons. 46:39-44.

Landry, M.S. and T.L. Thurow. 1997. Function and design of vegetation filter strips: An annotated bibliography. Texas State Soil and Water Conservation Board Bull. No. 97-1. Temple, Tex.

Larson, W.E., M.J. Lindstrom, and T.E. Schumacher. 1997. The role of severe storms in soil erosion: a problem needing consideration. J. Soil and Water Cons. 52:90-95.

Linse, S.J. 1992. The influence of ground cover on upland range erosion. M.S. Thesis. Univ. Wyoming. Laramie, Wyo. 98 p.

Linse, S.J., D.E. Mergen, J.L. Smith, and M.J. Trlica. 2001. Upland erosion under a simulated most damaging storm. J. Range Manage. 54:356-361.

Lowrance, R., J.K. Sharpe, and J.M. Sheridan. 1986. Long-term sediment deposition in the riparian zone of a coastal plain watershed. J. Soil and Water Cons. 41:266-271.

Magette, W.L., R.B. Brinsfield, R.E. Palmer, and J.D. Wood. 1989. Nutrient and sediment removal by vegetated filter strips. Trans. Am. Soc. Agr. Eng. 32:663-667.

McEldowney, R.R. 1999. Montane riparian surface hydrology and sediment filtration as affected by cattle disturbance. M.S. Thesis. Colorado State Univ., Fort Collins, Colo. 163 p.

Moss, A.J. 1988. The effects of flow-velocity variations on rain-driven transportation and the role of rain impact in the movement of solids. Aust. J. Soil Res. 26:443-450.

National Research Council (NRC). 1993. Soil and Water Quality: An Agenda for Agriculture. National Academy Press. Washington, D.C. $516 \mathrm{p}$.

Novotny, V. and H. Olem. 1994. Water Quality: Prevention, Identification, and Management of Diffuse Pollution. Van Nostrand Reinhold. New York. 1054 p.
Osborne, L.L. and D.A. Kovacic. 1993. Riparian vegetated buffer strips in water quality restoration and stream management. Freshwater Bio. 29:243-250.

Packer, P.E. 1953. Effects of trampling disturbance on watershed condition, runoff, and erosion. J. Forestry 51:28-31.

Pearce, R.A., M.J. Trlica, W.C. Leininger, D.E. Mergen, and G. Frasier. 1998a. Sediment movement through riparian vegetation under simulated rainfall and overland flow. J. Range Manage. 51:301-308.

Pearce, R.A., M.J. Trlica, W.C. Leininger, J.L. Smith, and G.W. Frasier. 1997. Efficiency of grass buffer strips and vegetation height on sediment filtration in laboratory rainfall simulations. J. Environ. Qual. 26:139-144.

Pearce, R.A., G.W. Frasier, M.J. Trlica, W.C. Leininger, J.D. Stednick, and J.L. Smith. 1998b. Sediment filtration in a montane riparian zone under simulated rainfall and overland flow. J. Range Manage. 51:309-314.

Prosser, I.P., W.E. Dietrich, and J. Stevenson. 1995. Flow resistance and sediment transport by concentrated flow in a grassland valley. Geomorphology 13:71-86.

Rogers, R.D. and S.A. Schumm. 1991. The effect of sparse vegetation cover on erosion and sediment yield. J. Hydrol. 123:19-24.

SAS. 1996. SAS System for Windows Version 6.12. Cary, N.C.

Simanton, J.R., M.A. Weltz, and H.D. Larsen. 1991. Rangeland experiments to parameterize the water erosion prediction project model: vegetation canopy effects. J. Range Manage. 44:276-282.

Spaeth, K.E., M.A. Weltz, H.D. Fox, and F.B. Pierson. 1994. Spatial pattern analysis of sagebrush vegetation and potential influences on hydrology and erosion. pp. 35-50. In: W.H. Blackburn, F.B. Pierson, G.E. Schumann, and R. Zartman (eds.) Variability in Rangeland Water Erosion Processes. SSSA Special Pub. No. 38. Madison, Wisc

Swanson, N.P. 1965. Rotating-boom rainfall simulator. Trans. Amer. Soc. Agr. Eng. 8:71-72.

Thurow, T.L., W.H. Blackburn, and C.A. Taylor, Jr. 1986. Hydrologic characteristics of vegetation types as affected by livestock grazing systems, Edwards Plateau, Texas. J. Range. Manage. 39:505-509.

Thurow, T.L., W.H. Blackburn, and C.A. Taylor, Jr. 1988. Infiltration and interrill erosion responses to selected livestock grazing strategies, Edwards Plateau, Texas. J. Range Manage. 41:296-302.

USDA, Soil Conservation Service and Forest Service. 1980. Soil survey report. Larimer County, CO. U.S. Govt. Print. Off. 239-812/48. Washington, D.C.

Welsch, D.J. 1991. Riparian Forest Buffers: Function and Design for Protection and Enhancement of Water Resources. USDA Forest Serv. NA-PR-07-91. Radnor, Penn. $24 \mathrm{p}$. 